\title{
Graham Little-Piccardi-Lassueur syndrome in a male patient:
}

a case report

\author{
Sevgi Kulaklı, İlkay $\mathrm{Ay}^{2} \odot$ \\ ${ }^{1}$ Department of Dermatology, Giresun University School of Medicine, Giresun, Turkey \\ ${ }^{2}$ Department of Pathology, Giresun University Prof. Dr. A. İlhan Özdemir Training and Research Hospital, Giresun, Turkey
}

\begin{abstract}
Graham Little-Piccardi-Lassueur syndrome is a type of lichen planopilaris characterized by the triad of patchy cicatricial alopecia of the scalp, non-cicatricial alopecia of the axilla and pubis, and follicular spinous papules on the body, scalp or both. This rare syndrome primarily affects middle-aged postmenopausal women with only three male cases being reported in literature. Herein we report a 53-year-old man who is fourth male patient diagnosed with Graham Little-Piccardi-Lassueur syndrome up to now.

Keywords: Graham Little-Piccardi-Lassueur syndrome, lichen planopilaris, male
\end{abstract}

\begin{abstract}
raham Little-Piccardi-Lassueur syndrome (GLPLS) is a type of lichen planopilaris characterized by the triad of patchy cicatricial alopecia of the scalp, non-cicatricial alopecia of the axillae and pubis, and follicular spinous papules on the body, scalp or both [1]. It is more common in postmenopausal women, with only few male cases being reported in literature [2]. Here we report a 53-year-old man diagnosed with GLPLS who is fourth male patient in the literature.
\end{abstract}

\section{CASE PRESENTATION}

A 53-year-old male patient presented with loss of hair on scalp, axilla, pubic region, arms and legs. The symptoms had started 40 years ago with hair loss on scalp, over the years the hair loss spread axilla, pubic region, arms and legs. He also complained of small pruritic lesions on the trunk, abdomen, forearms and thighs. He has no family history and received no treatment before.

Scarring alopecia on parietal area of scalp with multiple dilated follicular orifices plugged with keratotic debris and perifollicular violaceous hyperpigmentation was present on examination. There was axillar and pubic hypotrichosis without skin atrophy. Multiple follicular-oriented keratotic papules, perifollicular erythema and hair loss were present on the trunk, forearms and legs (Fig. 1).

Laboratory tests including hemogram, blood sugar, renal, liver and thyroid function tests, viral markers for hepatitis B and C, and serum antinuclear antibody levels were normal. Skin biopsy from the follicular papules on forearms showed follicular plugging, necrotic keratinocytes, basal vacuolar degeneration and dense band-like lymphocytic infiltration in superior segment of follicular epithelium (Fig. 2). Based on these findings, the patient was diagnosed with GLPLS and oral isotretinoin and topical corticosteroid treatments were started. 

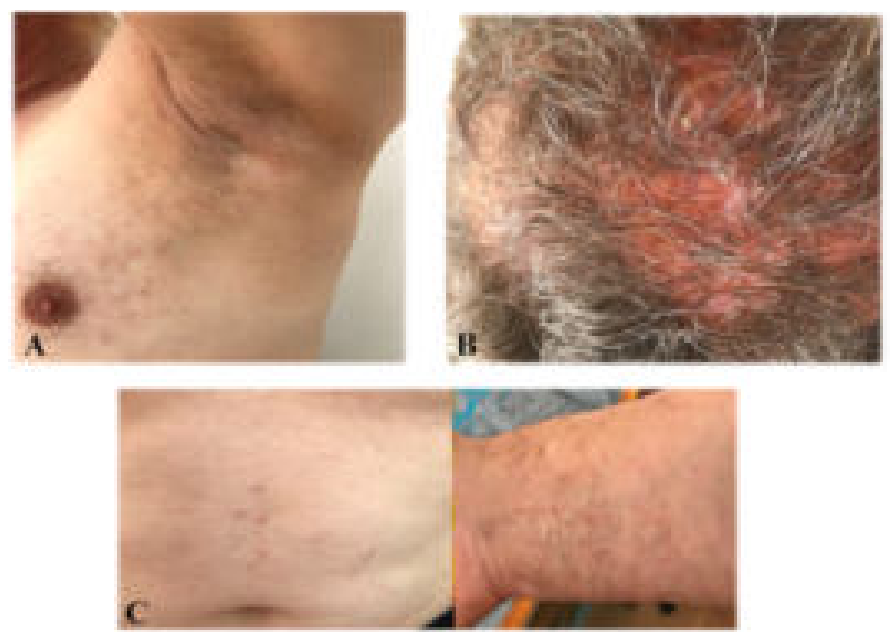

Fig. 1. (A) Axillar hypotrichosis without skin atrophy, (B) Alopecic areas with perifolicular erythema and desquamation, and (C) Folicular keratoic papules on abdomen and forearms.

\section{DISCUSSION}

GLPLS was initially described by Picardi in 1913 as a case of progressive scalp cicatricial alopecia, noncicatricial alopecia in the axilla and pubic region, and follicular spinous papules on the trunk and extremities. Graham Little, in 1915 published a similar case of a woman observed by Lassueur, followed by many similar reports later [3]. A Pubmed search from 1951 to 2018 produced fewer than 50 cases of GLPLS in the literature and only three of them were male [4-6].

The etiology of GLPLS is unknown, but it is likely similar to the T-cell mediated immunological mechanism that triggers the clinical expression of lichen planus [7]. An autoimmune response against the inner centromere protein (INCENP) was reported in a

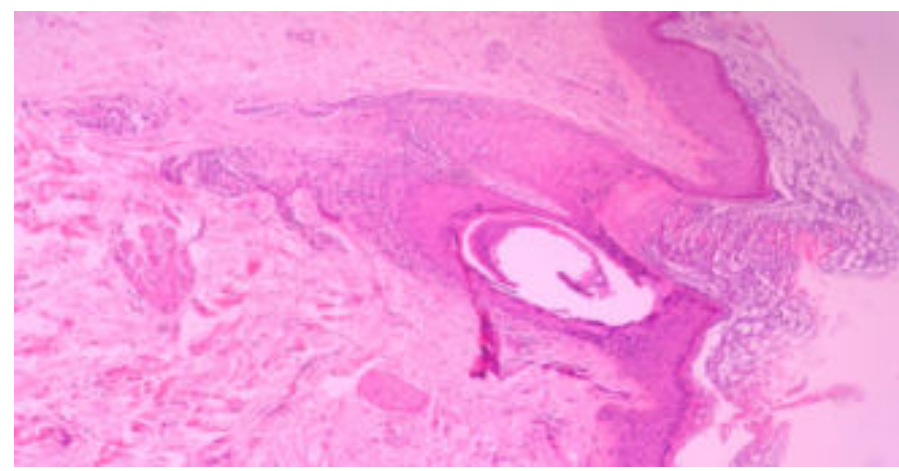

Fig. 2. Follicular plugging, necrotic keratinocytes, basal vacuolar degeneration and lymphocytic infiltration of follicular epithelium. patient with GLPLS. This protein is considered to be one of main antigen in this syndrome [8]. Few cases describing a familial pattern (HLA DR-1), association with hepatitis B vaccination and two female patients with androgen insensitivity syndrome have been reported [9-12].

Clinically, scarring alopecia often precedes the follicular eruption and the course of disease is slowly progressive [13]. Pruritus often can be severe although it is not always constant [4]. Most patients present with well-defined clinical findings that represent symptoms of the triad of GLPLS; however these findings need not present simultaneously [9]. Histopathology reveals a perifollicular lymphocytic infiltrate at the level of the infindibulum and the isthmus, along with vacuolar changes of the outer root sheath. More developed cases show perifollicular fibrosis and epithelial atrophy at the level of the infindibulum and the isthmus [14].

Treatment of GLPLS is really difficult. Topical, intralesional and systemic corticosteroids, retinoids, psoralen plus ultraviolet A (PUVA) photochemotherapy, antimalarials, topical tacrolimus, thalidomide and cyclosporin have been used with limited success [15].

\section{CONCLUSION}

In conclusion, we reported this case because of extreme rarity of presentation in males. When similar clinical findings seen in a male patient like this case, GLPLS should be suspected.

\section{Informed consent}

Written informed consent was obtained from the patient for publication of this case report and any accompanying images.

\section{Conflict of interest}

The authors declared that there are no potential conflicts of interest with respect to the research, authorship, and/or publication of this article.

\section{REFERENCES}

1. Odom RB, James WD, Berger TG, editors. Andrews' Diseases 
of the skin. Lichen planus and reletad conditions. 9th ed. Philadelphia: WB Saunders Company, 2000: pp. 274-5.

2. Assouly P, Reygagne P. Lichen planopilaris: update on diagnosis and treatment. Semin Cutan Med Surg 2009;28:3-10. 3. Graham-Little EG. Folliculitis decalvans et atrophicans. Br J Dermatol 1915;27:183-5.

4. Srivastata M, Mikkilineni R, Konstadt J. Lassueur-Graham Little-Piccardi syndrome. Dermatol Online J 2007;13:12.

5. Pai VV, Kikkeri NN, Sori T, Dinesh US. Graham LittlePicardi-Lassueur syndrome: an unusual variant of follicular lichen planus. Int J Trichology 2011;3:28-30.

6. Laszlo FG. Graham Little-Picardi-Lassueur syndrome: a case report and review of the syndrome in men. Int $\mathrm{J}$ Dermatol 2014;53:1019-22.

7. Teherney G, Nenoff P. Antigen mimicry followed by epitope spreading: a pathogenetic trigger for the clinical morphology of lichen planus and its transition to Graham Lassueur Piccardi Little syndrome and keratosis lichenoides chronic - Medical hypotesis or reality? Ann Bras Dermatol 2009;84:682-8.

8. Rodriguez-Bayona B, Ruchaud S, Rodriguez C, Linares M, Astola A, Ortiz M, et al. Autoantibodies against the chromosomal passenger protein INCENP found in a patient with Graham Little-
Picardi-Lassueur syndrome. J Autoimmune Dis 2007;4:1.

9. Viglizzo G, Verrini A, Rongioletti F. Familial LassueurGraham Little-Piccardi syndrome. Dermatology 2004;208:142-4. 10. Bardazzi F, Landi C, Orlandi C, Neri I, Varotti C. Graham Little-Piccardi-Lassueur syndrome following HBV vaccination. Acta Derm Venereol 1999;79:93.

11. Vega Gutiérrez J, Miranda-Romero A, Pérez Milán F, Martínez García G. Graham Little-Piccardi-Lassueur syndrome associated with androgen insensitivity syndrome (testicular feminization). J Eur Acad Dermatol Venereol 2004;18:463-6.

12. Graham Little-Picardi-Lassueur syndrome in a patient with androgen insensitivity syndrome. Int J Dermatol 2016;55:211-2. 13. Ghislain PD, Van Eeckhout P, Ghislain E. Lassueur-Graham Little-Piccardi syndrome: a 20-year follox-up. Dermatology 2003;206:391-2.

14. Elder DE, Elenitsas R, Johnson BL, Murthy GF, editors. Lever's Histopathology of skin. Non infectious eythematous papular and squamous disease. 9th ed. Philadelphia: Lippincott William, 2005: pp. 179-214.

15. Hixon C, Blattner CM, Hurd D. Graham-Little-PiccardiLassueur syndrome: a case report. JAOCD 2015;33:36-7. 